\title{
STRESS TOLERANCE AND ANTIBIOTIC SUSCEPTIBILITY OF CRONOBACTER SPP. ISOLATED FROM POWDERED INFANT FOR- MULA RETAILED IN NIGERIA
}

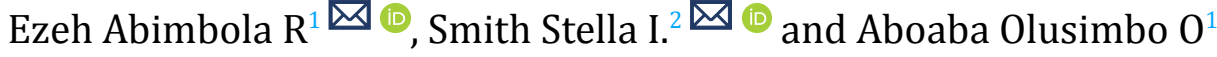 \\ ${ }^{1}$ Department of Microbiology, Faculty of Science, University of Lagos, Akoka, Nigeria \\ ${ }^{2}$ Department of Molecular Biology and Biotechnology, Nigerian Institute of Medical Research, Yaba, Lagos, Nigeria
}
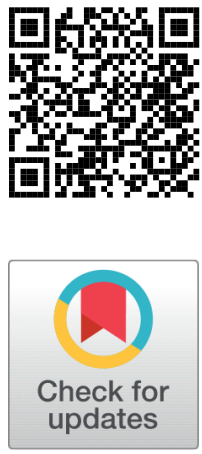

Received 1 June 2021

Accepted 13 June 2021

Published 30 June 2021

Corresponding Author

Ezeh Abimbola R, bimsal@yahoo.c

om

DOI $10.29121 /$

granthaalayah.v9.i6.2021.3989

Funding: This research received no specific grant from any funding agency in the public, commercial, or not-for-profit sectors.

Copyright: (C) 2021 The Author(s). This is an open access article distributed under the terms of the Creative Commons Attribution License, which permits unrestricted use, distribution, and reproduction in any medium, provided the original author and source are credited.

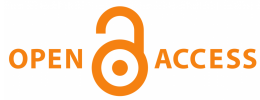

\section{ABSTRACT}

Cronobacter spp., is an emerging, opportunistic pathogen that causes infections such as septicaemia, meningitis and necrotizing enterocolitis in neonates and infants, and can sometimes lead to death. There is zero tolerance for the presence of Cronobacter spp. in all powdered infant formulae because of the high mortality rate $(80 \%)$ associated with Cronobacter spp. infections. Three Cronobacter spp. (CS14, CS17 and CS124) isolated from PIF retailed in Nigeria were exposed to different levels of stress ( $\mathrm{pH}$, osmotic, oxidative, heat, bile and desiccation). The biofilm production ability of the isolates was investigated and the susceptibility of the isolates to different antibiotics was carried out using the Microscan MIC panel. Variation in stress response was observed in the isolates with no consistent pattern. The CS 17 (Cronobacter sakazakii) and CS 124 (Cronobacter sakazakii) showed the highest tolerance to stress on the average. All the isolates exhibited the ability to produce biofilm ranging from $1.30-2.0$ absorbances and were also sensitive to more than $95 \%$ of the antibiotics used in the Microscan MIC panel, with no resistance to any.

Keywords: Cronobacter, Powdered Infant Formula, Stress, Antibiotic Susceptibility

\section{INTRODUCTION}

Cronobacter spp. is an emerging opportunistic food-borne pathogen that has been associated with serious infections in neonates and infants as well as elderly and immuno-compromised adults Tall et al. (2015). Infantile disease presents clinically as meningitis, septicaemia or bacteraemia, and necrotizing enterocolitis in new-borns, particularly affecting premature or other immunocompromised infants Alsonosi et al. (2015), Farmer (2015), Holý and Forsythe (2014), Hunter and Bean (2013).

Studies have shown that Cronobacter spp contaminate a lot of foods including infant foods (powdered infant formula, follow-up formula), dried milk protein prod- 
ucts, cheese, liquorice, candies, dried spices, teas, nuts, herbs, vegetables, filth and stable flies, and powdered infant formula (PIF) or in milk powder production facilities and household environments Berthold-Pluta et al. (2017), Yan et al. (2015).

Powdered infant formula (PIF) milk has been epidemiologically linked to disease outbreaks caused by Cronobacter sakazakii Brengi et al. (2012), Farmer (2015), Pagotto and Farber (2009). The addition of non-heat-treated materials and environmental contamination during filling and packaging are the plausible causes of Cronobacter contamination of PIF since Cronobacter strains cannot survive after the standard pasteurization procedures Nazarowec-White and Farber (1997). Foodborne pathogens must overcome several hurdles after they enter the host to be able to establish and cause infection. However, the body defense mechanisms prevent serious infections. These include the strong acid condition in the stomach, the presence of bile salts, antimicrobial peptides, and other hostile conditions. Cronobacter sakazakii exhibits unusual resistance to growth conditions such as acid stress and growth at minimum $\mathrm{pH}$ values of $\sim 4.5$, although this value varies depending on the strain and type of acid Alvarez-Ordonez et al. (2012). Bile is an important antimicrobial component of the human digestive system, but growth has been observed for some C. sakazakii isolates at bile salt concentrations as high as 5\% Fakruddin et al. (2013). Cronobacter sakazakii is reported to be significantly more thermotolerant when compared with other members of the family Enterobacteriaceae Amalaradjou et al. (2014). This feature gives it a competitive advantage thereby facilitating its survival during improper PIF reconstitution Bai et al. (2019).

Cronobacter spp. appears to differ considerably in terms of their susceptibility to various antibiotics compared to many enteric bacteria. Antibiotic therapy is considered to be the common and preferred way to prevent the Cronobacter infection in humans Depardieu et al. (2007). Many studies have confirmed that Cronobacter strains can be effectively eliminated by antibiotics Hoque et al. (2010), Fei et al. (n.d.) however, prolonged use of antibiotics is undesirable as it may result in the development of Cronobacter antibiotic resistance strains YONEYAMA and KATSUMATA (2006), McMahon et al. (2007).

This study aimed at evaluating the survival strategies of Cronobacter spp. exposed to different stress conditions posed by $\mathrm{pH}$, temperature, osmotic potential, oxidative, heat, high bile concentrations, desiccation as well as antibiotics susceptibility.

\section{MATERIALS AND METHODS}

\section{Stress Tolerance of Cronobacter spp.}

Three Cronobacter spp. were isolated from a total of 154 powdered infant formula retailed in Nigeria Ezeh et al. (2016). All stress tolerance experiments on the isolates were performed in Luria-Bertani (LB) broth (Difco). Stationary-phase cell suspensions were obtained by inoculating $10 \mathrm{ml}$ of fresh Luria-Bertani (LB) broth with an isolated colony of each bacterium and incubated overnight at $37^{\circ} \mathrm{C}$. When required, 
the challenge medium was supplemented by adding $3 \mathrm{~N} \mathrm{HCl}$ (Sigma), $3 \mathrm{~N} \mathrm{NaOH}$ (Merck), or $30 \% \mathrm{H}_{2} \mathrm{O}_{2}$. Heat treatments were carried out at $60^{\circ} \mathrm{C}$. Once the temperature of the treatment medium ( $1 \mathrm{ml}$ of LB) was stabilized, an inoculum of 0.01 $\mathrm{ml}$ of each bacterial suspension was added. During heating, samples were removed and plated on Luria-Bertani (LB) agar. For acid, alkaline, and oxidative treatments, aliquots of stationary-phase cultures were inoculated $(1 \% \mathrm{v} / \mathrm{v}$ inoculation concentration) into Luria-Bertani (LB) broth supplemented with $\mathrm{HCl}(\mathrm{pH} 2.5), \mathrm{NaOH}(\mathrm{pH}$ $11.0)$, or $\mathrm{H}_{2} \mathrm{O}_{2}(30 \mathrm{mM})$. After incubation at room temperature, the survival rate was monitored periodically.

The effect of desiccation on the cells, was assessed by transfering 100- $\mu$ l aliquots of stationary-phase cultures into 96-well culture plates (Falcon). They were kept without lids in a $25^{\circ} \mathrm{C}$ incubator for air drying. Under these conditions the sample was kept for approximately $3 \mathrm{~h}$. Subsequently, plates were incubated at room temperature for up to 8 days, and bacterial survival pattern was determined after the rehydration of samples with addition of $100 \mu \mathrm{l}$ PBS.

The effect of osmotic stress was determined by inoculating, aliquots of stationaryphase cultures ( $1 \% \mathrm{v} / \mathrm{v}$ inoculation concentration) into Luria-Bertani (LB) broth supplemented with $\mathrm{NaCl}(8 \%)$.

Growth was determined on all occasions by preparing 10-fold serial dilutions in sterile Phosphate Buffered Saline (PBS) solution and suitable dilutions plated in duplicates on Luria-Bertani (LB) agar plates.The plates were incubated at $37^{\circ} \mathrm{C}$ for 24 - $48 \mathrm{~h}$ and viable cells counted and survival rate (\%) determined.

\section{Bile salts resistance assay}

To determine the bacterial resistance to bile salts, bacterial isolates were grown in Luria-Bertani (LB) broth for $24 \mathrm{~h}$ at $37^{\circ} \mathrm{C}$. From these $20 \mu \mathrm{l}$ was then inoculated into $1 \mathrm{ml}$ (1: 50) of fresh Luria-Bertani (LB) broth containing $0.3 \%$ bile salts. After 60 min and $24 \mathrm{~h}$ incubation at $37^{\circ} \mathrm{C}$, bacterial isolates were serially diluted and plated out on LB agar. The percentage survival of each isolate was calculated.

\section{Biofilm Formation of Cronobacter Isolates}

The isolates were sub cultured overnight on Brain Heart Infusion (BHI) agar. Each was grown in Tryptic Soy broth (TSB) without glucose at $37^{\circ} \mathrm{C}$ with agitation starting 16 to $24 \mathrm{~h}$ before inoculating into 96-well micro titre plates. Dilution (1: 100) of the overnight grown cultures in Tryptic Soy broth (TSB) was carried out and $200 \mu \mathrm{l}$ of each bacterial suspension was inoculated into sterile 96 -well polystyrene micro titre plates (Ref BD\# 353072). Micro titre plates were incubated for $24 \mathrm{~h}$ at $37^{\circ} \mathrm{C}$. After $24 \mathrm{~h}$ incubation, plates were washed gently three times with $200 \mu \mathrm{l}$ of phosphate buffered saline (PBS pH 7.3) using a multichannel pipette and the wells were emptied by flickering the plates. Bacteria were fixed with $200 \mu \mathrm{l}$ of Bouin's fixative for 30 min at room temperature in the dark, and then rinsed once with phosphate buffered saline (PBS). The fixed bacterial cells were stained with $200 \mu \mathrm{l}$ of $1 \%$ crystal violet for $30 \mathrm{~min}$ at room temperature in the dark, and then rinsed thoroughly with distilled water (4-5 times). The plates were air dried for $15 \mathrm{~min}$ and the cells were solubi- 
lized in $200 \mu \mathrm{l}$ of ethanol: acetone (80:20, v/v). After 15- $20 \mathrm{~min}$, the optical density at $570 \mathrm{~nm}$ was measured using a micro plate reader (Mullikan Spectrum, Thermo LabSystem).

\section{Antibiotic Susceptibility pattern of Cronobacter Isolates}

Using the same micro-swab and membrane used for identification by MALDITOF VITEK MS RUO, a suspension was created following the Lysis-Filtration process and set aside until an identification result was obtained from the VITEK MS. As cellular debris is lysed and filtered, bacteria left on the filter is used for suspension preparation. The suspension was then adjusted to a McFarland standard of 0.5 and used for direct antibiotic susceptibility testing on VITEK ${ }^{\circledR} 2$ System. VITEK ${ }^{\circledR} 2$ cards were inoculated following manufacturers instruction. The ID from VITEK MS was introduced into the VITEK ${ }^{\circledR} 2$ system to allow it to choose the correct interpretive criteria. The resulting MIC was translated into clinical categories of susceptible, intermediate, or resistant following the Clinical and Laboratory Standards Institute (CLSI) recommendations (M45-A2/ M100-S22). The antibiotics used were amikacin $(<16 \mu \mathrm{g} / \mathrm{ml})$, amp/sulbactam $(<8 / 4 \mu \mathrm{g} / \mathrm{ml})$, ampicillin $(<8 \mu \mathrm{g} / \mathrm{ml})$, aztreonam $(<4$ $\mu \mathrm{g} / \mathrm{ml})$, cefepime $(<4 \mu \mathrm{g} / \mathrm{ml})$, cefotaxime $(<2 \mu \mathrm{g} / \mathrm{ml})$, ceftazidime $(<1 \mu \mathrm{g} / \mathrm{ml})$, ceftriaxone $(<8 \mu \mathrm{g} / \mathrm{ml})$, cefuroxime $(<4 \mu \mathrm{g} / \mathrm{ml})$, cefoxitin $(<8 \mu \mathrm{g} / \mathrm{ml})$ ciprofloxacin $(<1$ $\mu \mathrm{g} / \mathrm{ml})$ doripenem $(<0.5 \mu \mathrm{g} / \mathrm{ml})$, ertapenem $(<1 \mu \mathrm{g} / \mathrm{ml})$, gentamicin $(<4 \mu \mathrm{g} / \mathrm{ml})$, levofloxacin $(<2 \mu \mathrm{g} / \mathrm{ml})$, meropenem $(<1 \mu \mathrm{g} / \mathrm{ml})$, piperacillin-tazobactam $(<16 \mu \mathrm{g} / \mathrm{ml})$, tetracycline $(<4 \mu \mathrm{g} / \mathrm{ml})$, tigecycline $(<1 \mu \mathrm{g} / \mathrm{ml})$, tobramycin $(<4 \mu \mathrm{g} / \mathrm{ml})$, trimethoprim/sulfamethoxazole $(<2 / 38 \mu \mathrm{g} / \mathrm{ml})$ and cefazolin $(16 \mu \mathrm{g} / \mathrm{ml})$.

\section{RESULTS}

\section{Stress Response of Cronobacter Isolates}

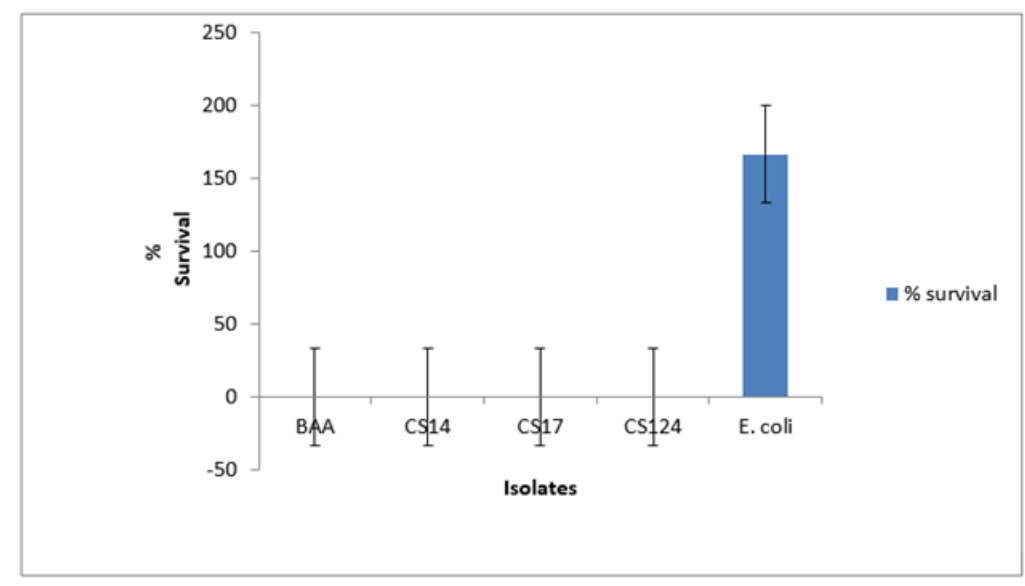

Figure 1 Rates of survival under $\mathrm{pH} 2.5$ for $60 \mathrm{~min}$

Variation in stress tolerance was observed with no consistent pattern. For acid tolerance among the Cronobacter spp., the survival rate was less than $1 \%$ for 60 min 
as shown in Figure 1 . At pH 11, CS 17 showed a survival rate of 34\% while CS 124 survived at $43 \%$ as shown in Figure 2 . CS 14 had a survival of just $10 \%$. At $30 \mathrm{~mm}$ $\mathrm{H}_{2} \mathrm{O}_{2}$ concentration for 60 min, only CS 124 survived with $0.2 \%$. This is shown in Figure 3 . At $60^{\circ} \mathrm{C}$ for $5 \mathrm{~min}$, survival ranged from $<1-4.6 \%$. CS 14 was the most sensitive at this temperature while CS 124 was the most resistant. This is shown in Figure 4 . All the isolates showed good tolerance to desiccation after eight days as shown in Figure 5 , with CS 124 having the highest survival percentage of about $75 \%$.

At $8 \% \mathrm{NaCl}$ concentration for $60 \mathrm{~min}$, all isolates survived well with a range from $36-55 \%$ as shown in Figure 6 . Bile concentration at $0.3 \%$ for $24 \mathrm{~h}$ had no negative effect on all isolates as shown in Figure 7. The isolates were able to grow under this concentration.

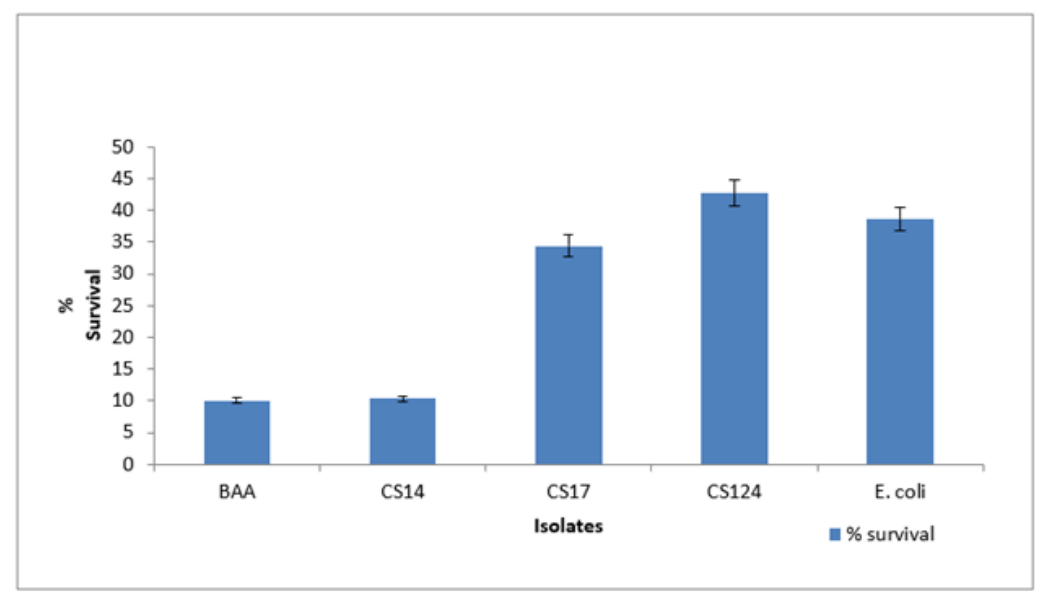

Figure 2 Rates of survival under $\mathrm{pH} 11$ for $60 \mathrm{~min}$

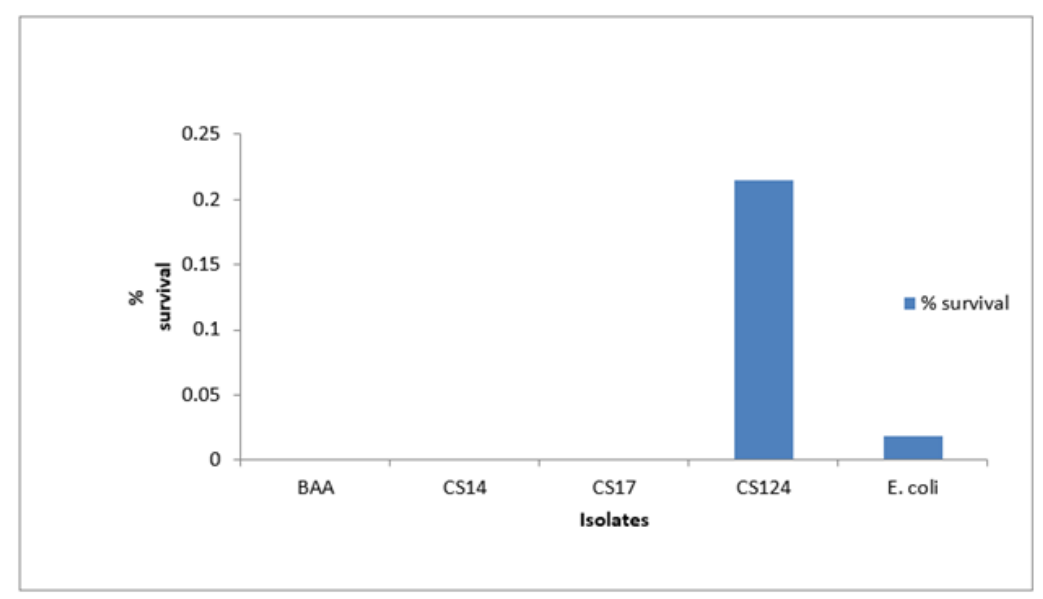

Figure 3 Rates of survival under $30 \mathrm{mM} \mathrm{H}_{2} \mathrm{O}_{2}$ for $60 \mathrm{~min}$

\section{Biofilm Formation of Cronobacter Isolates}




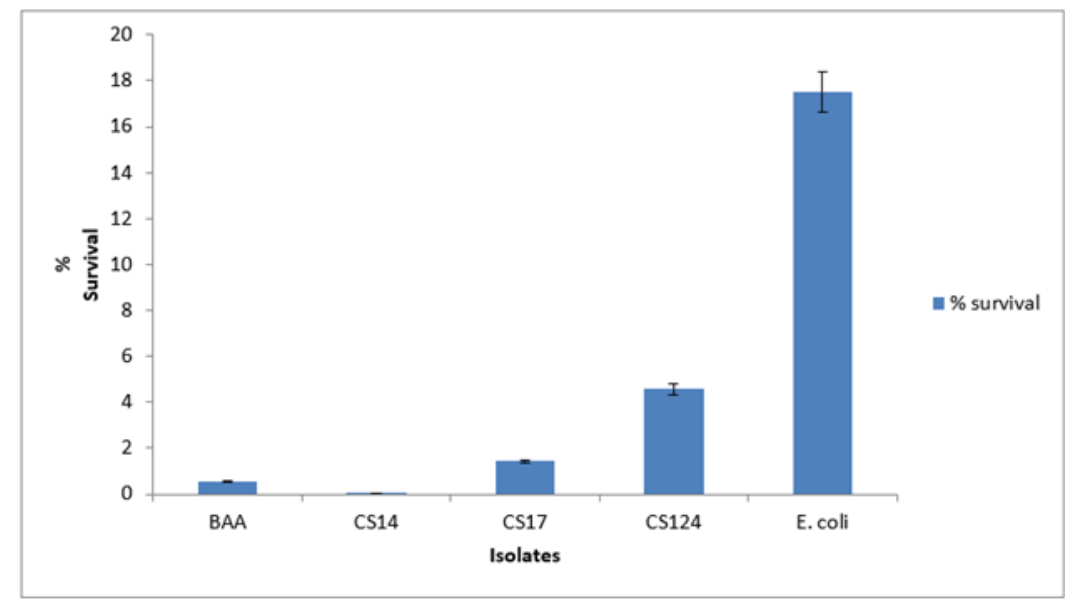

Figure 4 Rates of survival under $60^{\circ} \mathrm{C}$ for $5 \mathrm{~min}$

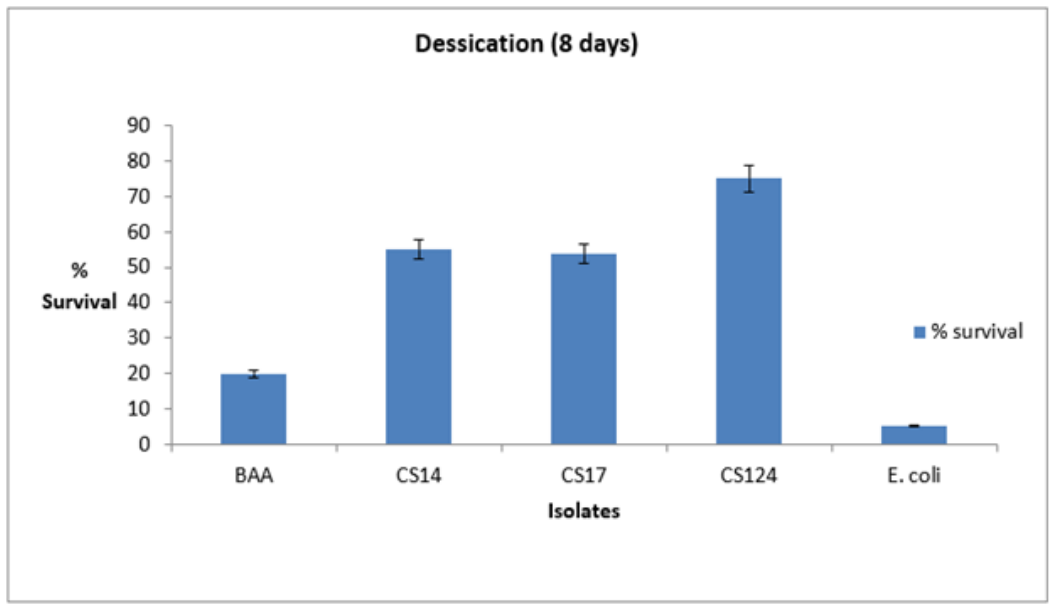

Figure 5 Survival at 8 days of Desiccation

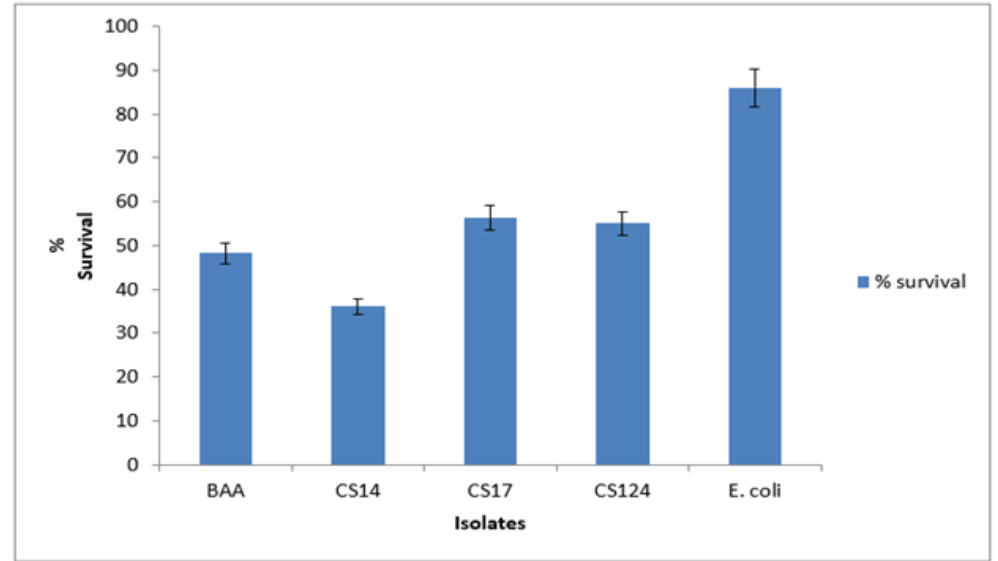

Figure 6 Rates of survival under $8 \% \mathrm{NaCl}$ for $60 \mathrm{~min}$ 


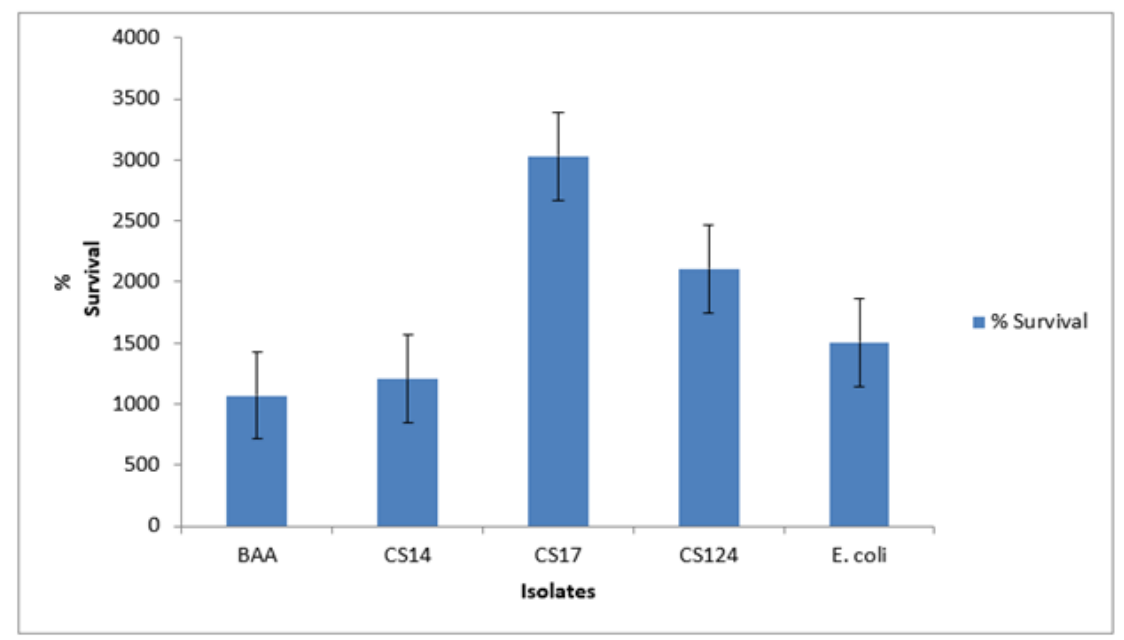

Figure 7 Rates of survival under $0.3 \%$ Bile for $24 \mathrm{~h}$

All the isolates demonstrated very good abilities to produce biofilm ranging from about $1.3-1.7$ at OD 570nm as shown in Figure 8.

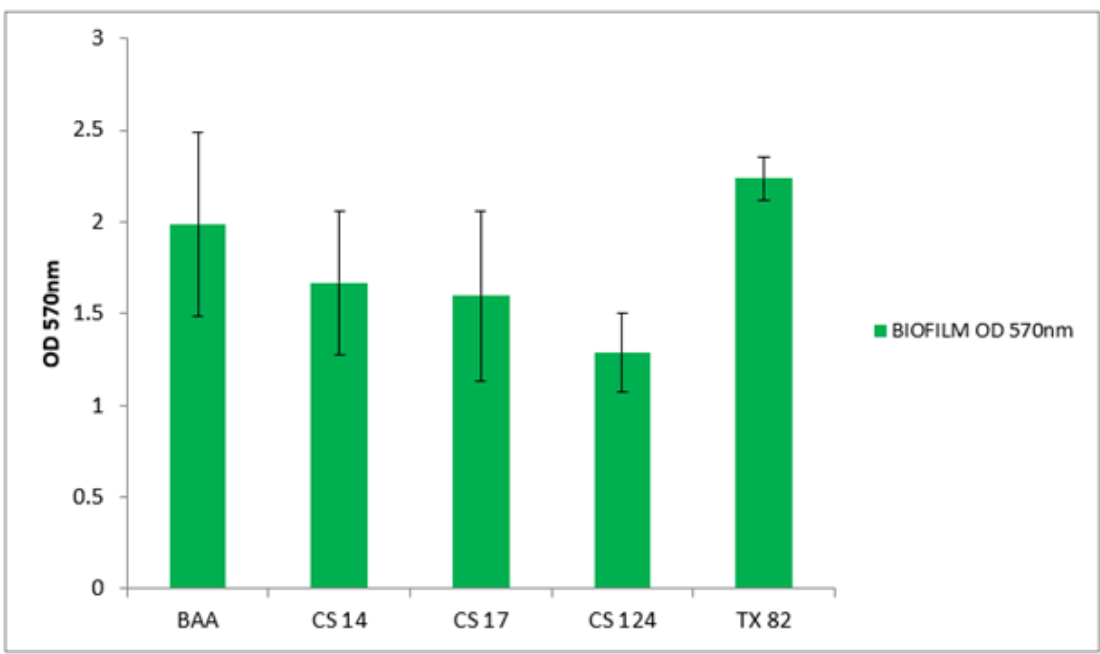

Figure 8 Biofilm Formation of Cronobacter Isolates at optical density (OD) 570

\section{Antibiotic susceptibility Testing}

All the isolates were sensitive to most of the antibiotics (>95\%) tested based on the Interpretive Breakpoints as indicated in Clinical and Laboratory Standards Institute (CLSI) document M45-A2 or M100-S22. Intermediate response to Cefazolin at an MIC of $16 \mu \mathrm{g} / \mathrm{ml}$ was observed as shown on Table 1 . There was no resistance observed. 
Table 1 Antibiotics Sensitivity Results with Minimum Inhibitory Concentration (MIC)

\begin{tabular}{|lll}
\hline Drug & MIC $(\mu \mathbf{g} / \mathbf{m l})$ & Interpretation \\
\hline Amikacin & $<16$ & $\mathrm{~S}$ \\
\hline Amp/Sulbactam & $<8 / 4$ & $\mathrm{~S}$ \\
\hline Ampicillin & $<8$ & $\mathrm{~S}$ \\
\hline Aztreonam & $<4$ & $\mathrm{~S}$ \\
\hline Cefepime & $<4$ & $\mathrm{~S}$ \\
\hline Cefotaxime & $<2$ & $\mathrm{~S}$ \\
\hline Ceftazidime & $<1$ & $\mathrm{~S}$ \\
\hline Ceftriaxone & $<8$ & $\mathrm{~S}$ \\
\hline Cefuroxime & $<4$ & $\mathrm{~S}$ \\
\hline Cefoxitin & $<8$ & $\mathrm{~S}$ \\
\hline Cefazolin & 16 & $\mathrm{I}$ \\
\hline Ciprofloxacin & $<1$ & $\mathrm{~S}$ \\
\hline Doripenem & $<0.5$ & $\mathrm{~S}$ \\
\hline Ertapenem & $<1$ & $\mathrm{~S}$ \\
\hline Gentamicin & $<4$ & $\mathrm{~S}$ \\
\hline Levofloxacin & $<2$ & $\mathrm{~S}$ \\
\hline Meropenem & $<1$ & $\mathrm{~S}$ \\
\hline Pip/Tazo & $<16$ & $\mathrm{~S}$ \\
\hline Tetracycline & $<4$ & $\mathrm{~S}$ \\
\hline Tigecycline & $<1$ & $\mathrm{~S}$ \\
\hline Tobramycin & $<4$ & $\mathrm{~S}$ \\
\hline Trimeth/Sulfa & $<2 / 38$ & $\mathrm{~S}$ \\
\hline S = Susceptible; I $=$ Intermediate; Amp $=$ Ampicillin; Pip \\
= Piperacillin; Tazo $=$ & Tazobactam & \\
\hline
\end{tabular}

\section{DISCUSSION}

The gastric microbial barriers of the stomach and small intestine decrease the chance of colonization by pathogens but do not provide protection against bacteria that have adapted to survive within these extremely harsh conditions. Enteric bacteria have mechanisms that allow for survival and proliferation within the human gut Merritt and Donaldson (2009). Cronobacter exhibit unusual resistance to heat, desiccation and acid stress growth conditions compared with other members of the family Enterobacteriaceae Dancer et al. (2009). The ability of Cronobacter spp. to withstand these stresses is crucial for their survival, persistence and infectivity. CS 14, CS 17 and CS 124 have demonstrated tolerance to several food- and host-related stresses (acid, alkaline, osmotic, oxidative, and heat stresses, and desiccation).

The gastric $\mathrm{pH}$ of infants six days old varies with age from a fasting $\mathrm{pH}$ of 2.9 to a value of 5.2 directly after eating Holton et al. (2014). As the infants gets older between 7-15 days old, the gastric pH ranges between 4.6 and 5.8. CS 14 (C. malonaticus) was the most resistant at $\mathrm{pH} 2.5$ for $60 \mathrm{~min}$ with a survival rate of less than 1\%. Wan-Ling et al. (2010) reported decline in the populations of C. sakazakii when exposed to gastric juice with pH 2.0 - 4.0 and an increase in $\mathrm{pH}$ led to an increase in 
the survival percentage. Because the $\mathrm{pH}$ of the gastric juice does not always remain low, there is a high possibility of Cronobacter surviving and causing an infection. At pH 11, all the isolates survived with CS 124 (C. sakazakii) having the highest survival of $43 \%$.

Cronobacter sakazakii is well known to be resistant to osmotic and dry stress Feeney and Sleator (2011). All isolates in this study survived $8 \% \mathrm{NaCl}$ for 60 min with a range of 36-55\%. The C. sakazakii isolates had a higher capacity to grow in the hyperosmotic media, in agreement with previous studies Fei et al. (n.d.), Alvarez-Ordonez et al. (2012). All the isolates showed resistance to 8 days of desiccation. This high tolerance to osmotic stress and desiccation may provide a competitive advantage in dry environments, such as is found in powdered infant formula.

Bile is an important antimicrobial component of the human digestive system and Gram-negative bacteria are inherently resistant to it. There was an increase in the viable population of all the isolates in this study at $0.3 \%$ bile concentration. This supports the work of Hsiao et al. (2010), which reported an increase in the viable population of Cronobacter sakazakii after exposure to $0.5 \%$ and $2.0 \%$ bile salt solution for $12 \mathrm{~h}$. The ability of enteric bacteria to survive in the presence of large quantities of bile salts is directly related to their ability to establish invasive infections Crawford et al. (2008).

Temperature abuse of reconstituted formula is a common risk factor in reported Cronobacter sakazakii outbreaks Caubilla-Barron et al. (2007); hence the need for temperature control to reduce microbial growth in reconstituted formula. At a temperature of $60^{\circ} \mathrm{C}$ for $5 \mathrm{~min}, \mathrm{CS} 124$ (C. sakazakii) was the most resistant while CS 14 (C. malonaticus) was the most sensitive. Arroyo et al. (2009) reported that the heat resistance of Cronobacter spp. varies widely among strains. Huertas et al. (2015) reported that when artificially inoculated powdered infant formula (PIF) was reconstituted at different water temperatures $\left(50,55,60,65,70^{\circ} \mathrm{C}\right)$ and cooled at different rates, C. sakazakii survived for long time periods in powdered formula and proliferated after reconstitution. Water at temperatures between 50 and $65^{\circ} \mathrm{C}$ for reconstitution did not provide a significant inactivation of $\mathrm{C}$. sakazakii cells. This supports the result of this present study. The rise in Cronobacter notoriety has prompted changes in the microbiological criteria for powdered infant formula (PIF) and reconstitution procedures. The FAO/WHO document (WHO, 2007) "Guidelines for the safe preparation, storage and handling of powdered infant formula" recommends reconstituting with water which has cooled to $70^{\circ} \mathrm{C}$ from boiling in order to destroy vegetative cells, reconstitute only the required amount and reduce the storage period prior to consumption as much as possible "World Health Organization. Guidelines For The Safe Preparation, Storage And Handling Of Powdered Infant Formula" (2007).

Cronobacter have been reported to attach to and from biofilms on stainless steel, glass, latex, silicon, polyvinyl chloride and polycarbonate Iversen et al. (2004). The biofilm serves as physical protective barrier from environmental stresses as well 
as host immune resistance mechanisms "FAO/WHO Enterobacter Sakazakii And Salmonella In Powdered Infant Formula (Meeting Report). Microbiological Risk Assessment Series 10. Rome" (2006). In this study, all the isolates demonstrated very strong abilities to produce biofilm ranging from 1.3 - 1.7 absorbance at OD 570 $\mathrm{nm}$. Biofilm formation is of special importance in the food industry because biofilms can act as a source of microbial contamination that might lead to spoilage of foods or contamination of food products undergoing processing Hartmann et al. (2010).

The antibiotic susceptibility pattern of the strains revealed that all the isolates were susceptible to amikacin, amp/sulbactam, ampicillin, aztreonam, cefepime, cefotaxime, ceftazidime, ceftriaxone, cefuroxime, doripenem, ertapenem, gentamicin, levofloxacin, meropenem, piperacillin-tazobactam, tetracycline, tigecycline, tobramycin, and trimethoprim/sulfamethoxazole with MIC ranging from $<0.5$ $<16 \mu \mathrm{g} / \mathrm{ml}$. Being susceptible to majority of the antibiotics used ( $>95 \%$ ) in this study will make the treatment of infections caused by any of the isolates effective. Intermediate response to cefazolin at $16 \mu \mathrm{g} / \mathrm{ml}$ was also observed in this study. This result is supported by Fei et al. (n.d.) who reported the antimicrobial susceptibility of 70 Cronobacter strains, representing 19 sequence types. Although multiple antibiotic resistance (mar) operons were found in Cronobacter Burgos and Varela (2002), the overall level of antibiotic resistance was low when compared with other food-borne pathogens.

\section{CONCLUSIONS AND RECOMMENDATION}

The use of hygienic measures during preparation and reconstitution of powdered infant formula (PIF) are essential. In addition, infant formula producers must enforce the use of guidelines aimed at decreasing the risks of product contamination with foodborne pathogens. The control of primary populations of Cronobacter spp. during the powdered infant formula (PIF) production process and prevention of post processing contamination can be ensured by using suitable microbiological guidelines for quality control and assurance. Sanitary practices for the preparation of infant formula in both the home and hospitals should be carefully controlled through the regular creation of the awareness that powdered infant formula (PIF) are not sterile but that they may contain potential pathogens.

\section{REFERENCES}

Alsonosi, A., Hariri, S., Kajsík, M., Oriešková, M., Hanulík, V., Röderová, M., Petrželová, J., Kollárová, H., Drahovská, H., Forsythe, S., \& Holý, O. (2015). The speciation and genotyping of Cronobacter isolates from hospitalised patients. European Journal of Clinical Microbiology \& Infectious Diseases, 34(10), 1979-1988. Retrieved from https://dx.doi.org/ 10.1007/s10096-015-2440-8 10.1007/s10096-015-2440-8

Alvarez-Ordonez, A., Begley, M., \& Hill, C. (2012). Polymorphisms In Rpos And Stress Tolerance Heterogeneity In Natural Isolates Of Cronobacter Sakazakii. Applied And Environ- 
mental Microbiology, 78(11), 3975-3984.

Amalaradjou, M. A., Kim, K., \& Venkitanarayanan, K. (2014). Sub-Inhibitory Concentrations of Trans-Cinnamaldehyde Attenuate Virulence in Cronobacter sakazakii in Vitro. International Journal of Molecular Sciences, 15(5), 8639-8655. Retrieved from https://dx.doi .org/10.3390/ijms15058639 10.3390/ijms15058639

Arroyo, C., Condón, S., \& Pagán, R. (2009). Thermobacteriological characterization of Enterobacter sakazakii. International Journal of Food Microbiology, 136(1), 110118. Retrieved from https://dx.doi.org/10.1016/j.ijfoodmicro.2009.09.013 10.1016/ j.ijfoodmicro.2009.09.013

Bai, Y., Yu, H., Guo, D., Fei, S., \& Shi, C. (2019). Survival and Environmental Stress Resistance of Cronobacter sakazakii Exposed to Vacuum or Air Packaging and Stored at Different Temperatures. Frontiers in Microbiology, 10(303), 1-7. Retrieved from https://dx.doi .org/10.3389/fmicb.2019.00303 10.3389/fmicb.2019.00303

Berthold-Pluta, A., Garbowska, M., Stefańska, I., \& Pluta, A. (2017). Microbiological quality of selected ready-to-eat leaf vegetables, sprouts and non-pasteurized fresh fruitvegetable juices including the presence of Cronobacter spp. Food Microbiology, 65, 221230. Retrieved from https://dx.doi.org/10.1016/j.fm.2017.03.005 10.1016/j.fm.2017 .03 .005

Brengi, S. P., O’Brien, S. B., Pichel, M., Iversen, C., Arduino, M., Binsztein, N., Jensen, B., Pagotto, F., Ribot, E. M., Stephan, R., Cernela, N., Cooper, K., \& Fanning, S. (2012). Development and Validation of a PulseNet Standardized Protocol for Subtyping Isolates ofCronobacterSpecies. Foodborne Pathogens and Disease, 9(9), 861-867. Retrieved from https://dx.doi.org/10.1089/fpd.2012.1161 10.1089/fpd.2012.1161

Burgos, J., \& Varela, M. (2002). Multiple Antibiotic Resistant Dairy Soil Bacteria. Abstracts Of The 102nd General Meeting Of The American Society For Microbiology; Salt Palace Convention Center. May 19-23, 2002, Session 25, Paper A-31.

Caubilla-Barron, J., Hurrell, E., Townsend, S., Cheetham, P., Loc-Carrillo, C., Fayet, O., Prère, M. F., \& Forsythe, S. J. (2007). Genotypic and Phenotypic Analysis of Enterobacter sakazakii Strains from an Outbreak Resulting in Fatalities in a Neonatal Intensive Care Unit in France. Journal of Clinical Microbiology, 45(12), 3979-3985. Retrieved from https://dx.doi.org/10.1128/jcm.01075-07 10.1128/jcm.01075-07

Crawford, R. W., Gibson, D. L., Kay, W. W., \& Gunn, J. S. (2008). Identification of a BileInduced Exopolysaccharide Required for Salmonella Biofilm Formation on Gallstone Surfaces. Infection and Immunity, 76(11), 5341-5349. Retrieved from https://dx.doi .org/10.1128/iai.00786-08 10.1128/iai.00786-08

Dancer, G. I., Mah, J. H., Rhee, M. S., Hwang, I. G., \& Kang, D. H. (2009). Resistance ofEnterobacter sakazakii(Cronobacterspp.) to environmental stresses. Journal of Applied Microbiology, 107(5), 1606-1614. Retrieved from https://dx.doi.org/10.1111/j.1365 -2672.2009.04347.x 10.1111/j.1365-2672.2009.04347.x

Depardieu, F., Podglajen, I., Leclercq, R., Collatz, E., \& Courvalin, P. (2007). Modes and Modulations of Antibiotic Resistance Gene Expression. Clinical Microbiology Reviews, 20(1), 79-114. Retrieved from https://dx.doi.org/10.1128/cmr.00015-06 10.1128/ cmr.00015-06

Ezeh, A. R., Aboaba, O. O., Murray, B. E., Tall, B. D., \& Smith, S. I. (2016). Phenotypic and Genotypic Characterization of Cronobacter isolated from Powdered Infant Formula Retailed in Nigeria. Journal of Food Research, 5(4), 65-65. Retrieved from https://dx.doi.org/ 10.5539/jfr.v5n4p65 10.5539/jfr.v5n4p65

Fakruddin, M., Rahaman, M. M., Ahmed, M. M., Hoque, M. M., Cronobacter, \& Sakazakii. (2013). 
Enterobacter Sakazakii): An Emerging Foodborne Pathogen. International Journal of Biomedical And Advance Research, 4, 349-359.

FAO/WHO Enterobacter Sakazakii And Salmonella In Powdered Infant Formula (Meeting Report). Microbiological Risk Assessment Series 10. Rome. (2006). Food And Agriculture Organization Of The United Nations/World Health Organization.

Farmer, J. J. (2015). My 40-Year History With Cronobacter/Enterobacter Sakazakii - Lessons Learned, Myths Debunked, And Recommendations. Frontiers In Pediatrics, 3(84), 1-12.

Feeney, A., \& Sleator, R. D. (2011). An in silico analysis of osmotolerance in the emerging gastrointestinal pathogenCronobacter sakazakii. Bioengineered Bugs, 2(5), 260-270. Retrieved from https://dx.doi.org/10.4161/bbug.2.5.17238 10.4161/bbug.2.5.17238

Fei, P., Jiang, Y., Feng, J., Forsythe, S., Li, R., Zhou, Y. E., \& Al. (n.d.). Antibiotic And Desiccation Resistance Of Cronobacter Sakazakii And C. Malonaticus Isolates From Powdered Infant Formula And Processing Environments. Frontiers In Microbiology, 8(316), 1-8.

Hartmann, I., Carranza, P., Lehner, A., Stephan, R., Eberl, L., \& Riedel, K. (2010). Genes Involved in Cronobacter sakazakii Biofilm Formation. Applied and Environmental Microbiology, 76(7), 2251-2261. Retrieved from https://dx.doi.org/10.1128/aem.00930-0910 .1128/aem.00930-09

Holton, T. A., Vijayakumar, V., Dallas, D. C., Guerrero, A., Borghese, R. A., Lebrilla, C. B., German, J. B., Barile, D., Underwood, M. A., Shields, D. C., \& Khaldi, N. (2014). Following the Digestion of Milk Proteins from Mother to Baby. Journal of Proteome Research, 13(12), 5777-5783. Retrieved from https://dx.doi.org/10.1021/pr5006907 10.1021/ pr5006907

Holý, O., \& Forsythe, S. (2014). Cronobacter spp. as emerging causes of healthcare-associated infection. Journal of Hospital Infection, 86(3), 169-177. Retrieved from https://dx.doi .org/10.1016/j.jhin.2013.09.011 10.1016/j.jhin.2013.09.011

Hoque, A., Ahmed, T., Shahidullah, M., Hossain, A., Mannan, A., Noor, K., Nahar, K., Ilias, M., \& Ahmed, D. (2010). Isolation and molecular identification of Cronobacter spp. from powdered infant formula (PIF) in Bangladesh. International Journal of Food Microbiology, 142(3), 375-378. Retrieved from https://dx.doi.org/10.1016/j.ijfoodmicro.2010 .07.019 10.1016/j.ijfoodmicro.2010.07.019

Hsiao, W.-L., Ho, W.-L., \& Chou, C.-C. (2010). Sub-lethal heat treatment affects the tolerance of Cronobacter sakazakii BCRC 13988 to various organic acids, simulated gastric juice and bile solution. International Journal of Food Microbiology, 144(2), 280284. Retrieved from https://dx.doi.org/10.1016/j.ijfoodmicro.2010.10.006 10.1016/ j.ijfoodmicro.2010.10.006

Huertas, J.-P., Álvarez Ordóñez, A., Morrissey, R., Ros-Chumillas, M., Esteban, M.-D., Maté, J., Palop, A., \& Hill, C. (2015). Heat resistance of Cronobacter sakazakii DPC 6529 and its behavior in reconstituted powdered infant formula. Food Research International, 69, 401-409. Retrieved from https://dx.doi.org/10.1016/j.foodres.2015.01.010 10 $.1016 /$ j.foodres.2015.01.010

Hunter, C. J., \& Bean, J. F. (2013). Cronobacter: an emerging opportunistic pathogen associated with neonatal meningitis, sepsis and necrotizing enterocolitis. Journal of Perinatology, 33(8), 581-585. Retrieved from https://dx.doi.org/10.1038/jp.2013.26 10.1038/ jp.2013.26

Iversen, C., Lane, M., \& Forsythe, S. J. (2004). The growth profile, thermotolerance and biofilm formation of Enterobacter sakazakii grown in infant formula milk. Letters in Applied Microbiology, 38(5), 378-382. Retrieved from https://dx.doi.org/10.1111/j .1472-765x.2004.01507.x 10.1111/j.1472-765x.2004.01507.x 
McMahon, M. A. S., Xu, J., Moore, J. E., Blair, I. S., \& McDowell, D. A. (2007). Environmental Stress and Antibiotic Resistance in Food-Related Pathogens. Applied and Environmental Microbiology, 73(1), 211-217. Retrieved from https://dx.doi.org/10.1128/aem.00578 -06 10.1128/aem.00578-06

Merritt, M. E., \& Donaldson, J. R. (2009). Effect of bile salts on the DNA and membrane integrity of enteric bacteria. Journal of Medical Microbiology, 58(12), 1533-1541. Retrieved from https://dx.doi.org/10.1099/jmm.0.014092-0 10.1099/jmm.0.014092-0

Nazarowec-White, M., \& Farber, J. M. (1997). Enterobacter sakazakii: a review. International Journal of Food Microbiology, 34(2), 103-113. Retrieved from https://dx.doi.org/ 10.1016/s0168-1605(96)01172-5 10.1016/s0168-1605(96)01172-5

Pagotto, F. J., \& Farber, J. M. (2009). Cronobacter spp. (Enterobacter sakazakii): Advice, policy and research in Canada. International Journal of Food Microbiology, 136(2), 238245. Retrieved from https://dx.doi.org/10.1016/j.ijfoodmicro.2009.05.010 10.1016/ j.ijfoodmicro.2009.05.010

Tall, B. D., Gangiredla, J., Gopinath, G., Yan, Q., Chase, H. R., Lee, B. E., \& Al. (2015). Development Of A Custom-Designed. Pan Genomic DNA Microarray To Characterize Strain-Level Diversity Among Cronobacter Spp. Frontiers In Pediatrics, 3(36), 1-11.

World Health Organization. Guidelines For The Safe Preparation, Storage And Handling of Powdered Infant Formula. (2007).

Yan, Q., Jarvis, G. K., Chase, R. H., Hebert, K., Trach, L. H., Lee, C. E., \& Al. (2015). A Proposed Harmonized LPS Molecular-Subtyping Scheme For Cronobacter Species. Food Microbiology, 50, 38-43.

YONEYAMA, H., \& KATSUMATA, R. (2006). Antibiotic Resistance in Bacteria and Its Future for Novel Antibiotic Development. Bioscience, Biotechnology, and Biochemistry, 70(5), 1060-1075. Retrieved from https://dx.doi.org/10.1271/bbb.70.1060 10.1271/bbb .70 .1060 